\section{Civil aviation}

SIR - Your leading article on 6 September, p.1 ("Poor show for aviation industry") complains that "civil air transport is not as accessible or cheap as it should be". Perhaps the judgement would be fairer had the article ended "as I would like it to be". The author has clearly not grasped the complexity of an airline operation. The technology necessary to take people around the world near or above the speed of sound costs money, and to do so safely requires one of the most intricate manmade systems most of us encounter. Add to this the requirement to ensure that flying is a positive experience for the customer and that there is a reasonable profit and to cope with political pressures from many governments.

As a pilot with a major international carrier I would hesitate to comment publicly on the financial wisdom of subcontracting aircraft component manufacture, an area which I recognize as only indirectly related to my area of competence.

19 Mountbatten Square,

R.J. ANDERSSON Windsor, Berkshire SL4 ISX, UK

\section{Indian science}

SIR - I would like to add to the explanations which have been given in your columns of the poor quality of research in Indian universities and institutes. The problem at many Indian universities and institutions is a lack of understanding concerning the philosophy of higher education and a lack of sincerity on the part of the academic faculty and administrative staff. There is also a perversion of the professorstudent relationship into what often resembles a master-servant relationship.

Many senior scientists from Indian universities and institutes work hard while in the West but when they return to India depend heavily on technicians and students in their laboratories. Another contributing factor is that scientists plan frequent long trips to the Western institutions. Their time in India is mostly spent on collecting money and making arrangements for their next trip. This situation deprives doctoral students of proper guidance from their professors. Often dissertations are presented to the university by the doctoral students in the absence of their major professor.

The concept of higher education in many Indian universities is misunderstood. Comprehensive solutions are required. Despite a huge cut in government support for scientific research in Europe and the United States during the past few years, the number of publications in a scientific journals is increasing. On the other hand, the Indian Government is spending a much greater percentage of the gross national product on science and technology than in of both graduates and non-graduates, these figures suggest that prospects for biochemistry graduates remain reasonably good and apparently considerably better than for biologists.

solution lies in increasing the commitment of all those involved in science.

PAWAN K. SAHARAN

West Virginia University,

School of Medicine,

Medical Center,

Morgantown, West Virginia 26506, USA

\section{Scientists' oath?}

SIR - Television dramas such as Threads and The Day After make us painfully aware of the great power that scientific and technical knowledge has for evil as well as good. A crucial question is the extent to which scientists, as individuals and as a profession, accept social and ethical responsibility for their research. I suggest that scientists, on graduation, take an oath or make an understanding that their work be for the benefit, rather than detriment, of mankind. Though such an oath would not legally prevent scientists from working on, for example, new nerve gases and new nuclear warhead systems, it might make a start to the establishment of a code of ethics for the scientific profession and bring this body into line with older institutions such as medicine and the church. Such a scientific Hippocratic oath might influence decisions made by individual scientists and a scientific code of ethics might answer an increasingly more popular groundswell of opinion that scientific "progress" in toto is not worth the associated risks to the survival of the human species.

JONATHON HOWARD

Department of Physiology,

University of Bristol Medical School,

University Walk,

Bristol BS8 ITD, UK

\section{Jobs for biochemists}

SIR - Richard Pearson's article "Is all science vocational?"' (Nature 310, 260; 1984) will no doubt be widely read and quoted. As regards the employment of biochemistry graduates, however, the figures obtained by the Biochemical Society, which has been conducting an annual employment survey for some years, indicate a somewhat less gloomy situation. Thus, in 1983, 12.4 per cent of new graduates were still unplaced at the end of the year with another 6.3 per cent unknown as regards employment. At least 80 per cent are known to have found useful occupation within 6 months of graduating, such as further biochemical training for higher degrees (25.4 per cent), biochemical employment ( 25.5 per cent), other further studies (9.7 per cent) or non-biochemical employment ( 9 per cent). In addition, 11.7 per cent went abroad, including overseas students returning home and British students taking jobs. Given the present general difficulties as regards employment
H.R.V. ARNSTEIN

Biochemical Society,

7 Warwick Court,

High Holborn,

London WC1R SDP, UK

RICHARD PEARSON REPLIES:

Professor Arnstein's letter provides valuable information about biochemists and highlights the range of employment they have entered in the past. However when making comparisons between subjects for example with biologists, it is important to compare like with like and to use common databases as was done in my article. While the statistics are capable of different interpretations, cross-referencing one source to another can lead to inappropriate comparisons.

SIR - In the article by Stephen Budiansky on the emotive subject both sides of the Atlantic, "Are antibiotics in animal feed a threat to human health?"' (Nature 4 October, p.407), a few statements cannot pass unchallenged.

For instance, the statement* that "none of the bacteria residing in the gut of farm animals is resistant" is just not true ${ }^{1}$. Rather than looking for evidence that animal pathogens constitute the source of $\mathrm{R}$ plasmids for human pathogens, as is suggested, evidence already points to the $R$ plasmid-carrying indigenous flora in the animal gut as the main reservoir ${ }^{2}$. This reservoir is being selected continously by the use of antibiotics for whatever purpose. The present debate, therefore, hinges on whether or not subinhibitory, rather than prophylactic or therapeutic, levels of antibiotics play the major role.

Further, the suggestion that the energy cost to bacteria of carrying $\mathbf{R}$ plasmids places them at a disadvantage is not scientifically substantiated. It is now recognized that many plasmids are stable entities of the bacterial cell. Also, antibiotic resistance determinants are sometimes genetically linked on the same plasmid with virulence determinants ${ }^{3}$ and consequently antibiotics select for both types of determinants.

Department of Microbiology,

University of Bristol Medical School, Bristol BS\& 1TD, UK

Linton, A.H. Vet, Rec, 108, 328-331 (1981).

2. Linton, A.H. \& Hinton, M.H. in Antimicrobials and Agriculture (ed. Woodbine, M.) 533-549 (Butterworths, London, 1984).

. Timoney, J.F. \& Linton, A.H. J. appl. Bact. 52, 417-424 (1982).

*This should have read "not all of the bacteria...", but was inadvertently changed in the editing. - Editor, Nature.

\section{Animal antibiotics}

